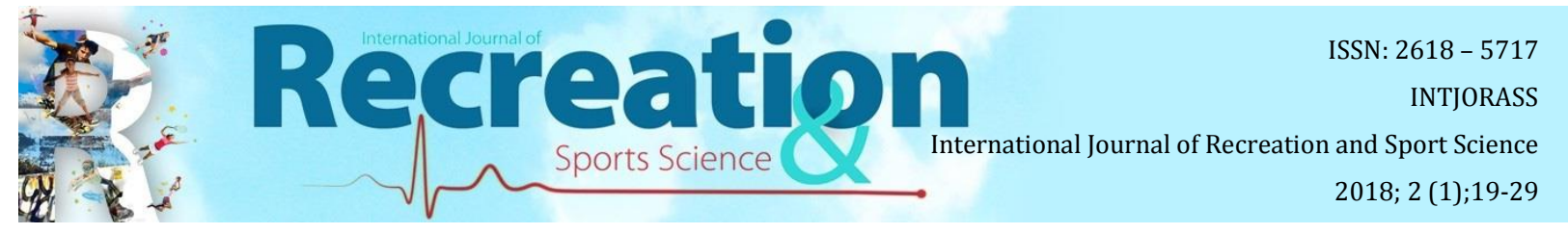

\title{
Outdoor and Indoor Sports that Require Skill Executive Branches of the Personality Types of Athletes
}

HASAN ERDEM MUMCU*

\author{
SEMA ALAY ÖZGÜL**
}

\begin{abstract}
There are many studies in the areas of personality and motivation. However, there are limited studies on the association of skills to personality trait and motivation in our country. The purpose of this study is to examine the effects of the personality types of the athletes, who perform sports requiring outdoor and indoor skills, on the motivation using the Basic Personality Scale for Turkish Culture and the Motivation in Sports Scale. The conclusions drawn here are thought to be that the motivations and personality traits of the athletes will contribute to the selection of the athletes in the future, the selection of the athletes' sports branches and the process of continuing the sports. The sample of the study consisted of 239 national athletes in judo, taekwondo, shooting, wrestling, table tennis, boxing, weightlifting, tennis, swimming, karate, bocce, billiards, chess, badminton and archery branches. Totally 239 national athletes participated in the survey, of which 98 are girls and 141 are boys. When comparing open skills required athletes with closed skills required athletes, the effects of gender, age, educational status, the age of sport, the age of national athletic age on personality types and motivations were examined by Multiple Regression Analysis, Binary and Partial Correlation Analysis. Statistically significant differences were found on the motivations of the athletes who perform sports that require both indoor and outdoor skills.
\end{abstract}

Keywords: Skill, Personality, Personality traits, Motivation, Sports, Sport activities.

\section{Açık ve Kapalı Becerileri İcra Eden Sporcuların Kişilik Tiplerinin Güdülenmeleri Üzerine Etkileri}

$\ddot{O} z$

Kişilik ve güdülenme alanlarında pek çok çalışma yapılmıştır. Fakat ülkemizde becerilerin, kişilik ve güdülenme ile ilişkilendirilmesi üzerine çalışmalar sınırlıdır. Bu araştırmanın amacı; Türk Kültürü için Temel Kişilik Ölçeği ve Sporda Güdülenme Ölçeği kullanılarak, açık ve kapalı beceri gerektiren sporları icra eden sporcuların kişilik tiplerinin, sporcuların güdülenmeleri üzerine etkileri incelenmiş̧ir. Buradan çıkan sonuçların sporcuların güdülerinin ve kişilik özelliklerinin ileride sporcuların seçimine, sporcuların spor dallarının seçimine ve spora devam etme süreçlerine katkı sağlamayacağı düşünülmektedir. Araştırmanın örneklemini ise; judo, tekvando, atıcılık, güreş, masatenisi, boks, halter, tenis, yüzme, karate, bocce, bilardo, satranç, badminton ve okçuluk dallarında milli olmuş 239 sporcu oluşturmaktadır. Araştırmaya katılan milli olmuş sporcuların, $98^{\circ} \mathrm{i} \mathrm{kız}, 141^{\mathrm{e} i} \mathrm{i}$ erkek olmak üzere toplam 239 sporcu katılmıştır. Açık beceri gerektiren sporcuların, kapalı beceri gerektiren sporcuları ile karşılaştırılmasında cinsiyet, yaş, eğitim durumu, spor yaşı, milli sporculuk yaşı değişkenlerinin kişilik tiplerinin ve güdülenmeleri üzerine etkilerini Çok Yönlü Regreasyon Analizi, İkili ve kısmi Kolarasyon Analizi ile incelenmiştir. Sonuç olarak, açık ve kapalı beceri gerektiren sporları icra eden sporcuların kişilik tiplerinin, sporcuların güdülenmeleri üzerinde istatistiksel anlamlı farklılıklar tespit edilmiştir.

Anahtar Kelimeler: Beceri, Kişilik, Kişilik özellikleri, Motivasyon, Spor, Spor aktiviteleri

\footnotetext{
*Hitit University, Sports Science Faculty, Çorum-TURKEY, erdemumcu@ gmail.com

** Marmara University, Sports Science Faculty, İstanbul-TURKEY, salay@ marmara.edu.tr
} 


\section{INTRODUCTION}

Athletes are faced with many difficulties such as working hours to show their best performance, healing process from injuries, competition stress, anxiety and pain of defeat. It is not enough for the athlete to have physical strength and ability to come through these difficulties, but at the same time, they have to be strong psychologically (Vallerand and Losier, 1999). It is necessary to determine the needs of the athletes in order to that they will feel best about themselves and get rid of the psychological pressures that the possibilities of winning and losing inherently present in the sports. The most important factor that keeps the athletes constantly in the sports environment and brings the athletes to success in sports is achieved with motivation. Motivation in sports researches focus on the reasons for participation, continuance and quitting of the sports. For example, why would a person choose to play soccer while the other would prefer to play tennis? Why does a marathoner spend 15-20 hours a week? Why do a parachutist jump from thousands of meters in height? These questions have been tried to be answered (Deci and Rayn, 1990b). For this reason, it is not surprising that such successful athletes and trainers care about the motivation in sports (Gould, 1982). Surveys reveal that the athletes are motivated by three main types of motivation (Deci and Rayn, 1985; Vallerand et al., 1987; Deci and Rayn, 1990a; Kazak, 2004; Rayn and Deci, 2007). While the sportsmen are intrinsically motivated by one side, the other side may experience extrinsic motivations or experience a sense of non-motivation sense (Vallerand and Losier, 1999, Rayn and Deci, 2007). In the researches based on the Free Will Theory (1985) and Valerand's (1987) hierarchical model of internal and external motivation, social factors such as achievement and defeat are stated that they are effective determinants on motivation in sports.

But these factors are also seen to be balanced by the sense of competence, autonomy and connection needs of sportsmen (Deci and Rayn, 1990a). The personality of Free Will Theory is described as "Intrinsically motivated, deliberate movements representing human activity and free will". According to the Free Will Theory, personal incentives, sense of personality, and perceived choices are the main determinants of behaviour (Martin and Mushett, 1996). Moreover, it is stated that behaviours arising from the intrinsic motivation or the good unification of personal values occur with free will, but the behaviours arising from both internal repressions and the inner reflections in the regard of social do not occur with free will (Rayn ve Deci, 2007). According to many studies, both situational and attitudinal autonomous motivation has generally led to more positive outcomes than controlled motivation (Deci and Rayn, 2012). In other words, in the sports environment, the behaviours that internally motivated give the result that the individuals are more willing and satisfying personally from the behaviours externally motivated (Vallerand et al., 1987; Deci and Rayn, 1990a). The most important feature of behaviours which occur by free-will is that it helps them to work very long hours on mastery and skill development in areas of interest to the individual. It draws a general framework on how we understand how this behavior occurs in the sports environment for intrinsic or extrinsic reasons (Hagger and Chatzisarantis, 2007; Standage and Ryan, 2012). In addition to having a solid personality structure in order for a person to be able to overcome difficult processes, such as doing constant training, he/she also needs a motivational ability that cannot be interrupted (Bakker et al., 1990). The fact that the most important element of personality is expressed as intrinsic motivation reveals the question of how much the motivation, which is the cause of the being done the movement, is affected by personality.

From this information, it must have an effect on the motivation of the athletes' personalities and the size of this effect is worth investigating.

\section{METHOD}

\section{Participants}

The universe of the research is composed of sportsmen who have served in Turkish 
National Teams. The sample of the study consisted of 239 national athletes in judo, taekwondo, shooting, wrestling, table tennis, boxing, weightlifting, tennis, swimming, karate, bocce, billiards, chess, badminton and archery branches. Athletes participating in the survey are at least once national athletes. Totally 239 national athletes participated in the survey, of which 98 are girls and 141 are boys.

\section{Data Collection Tools}

Three surveying instruments were used to collect data in the survey. The first surveying instrument which is developed by, Pelletier, Fortier, Vallerant, Tuson, Briere and Blais (1995), adopted by Kazak (2004) is Sport Motivation Scale (SMS).

Sport Motivation Scale (SMS) consists of 3 sub-dimensions and 28 items. This subdimensions consist Knowing and Achieving (8 items), Living with stimuli (4 items), External regulation (4 items), introjection (4 items), Identification (4 items), Non-motivation (4 items), Extrinsic motivation (4 items), Intrinsic motivation (4 items). In order to determine what kind of motivations the athletes live in the sports environment, the scale used is the Likert type and it is evaluated between 1 (totally not suitable) and 7 (totally suitable).

The second surveying instrument is 'Big Five' which is developed by John Donahue and Urban (1991). It is adapted to Turkey by Gençöz ve Öncül (2012) and its name is "Basic Personality Scale for Turkish Culture". The scale consists of 5 sub-dimensions and 44 items. This sub-dimensions consist Extroversion (8 items), Reconciliation (9 items), Attentive-Honest (9 items), Emotional balance ( 8 items), Open-Mindedness (10 items). The scale used is the Likert type and it is evaluated between 1 (strongly agree) and 5 (strongly disagree).

In addition, when collecting data, the personal information of the participants was also obtained. These were gender, age, educational status, sports age information. Before starting the data collection process, it was negotiated with officials from the sports federations and camp training centers affiliated to GSGM. Then, data collection tools were applied to sportsmen participating in the survey.

\section{Analysis of Data}

In this study, multiple regression analysis was applied to the collected data to test the effect of athletes' personality types on the motivation. Multiple regression analysis is a type of analysis for predicting a dependent variable based on two or more independent variables (personality types) that are related to the dependent variable (with motivation) (Büyüköztürk, 2011: 98). In addition to multiple regression analysis, the personality types of the athletes and their motivations was calculated by a correlation analysis (Pearson correlation coefficient). A descriptive statistical method was used for the personal data in the analysis of the data obtained from the athletes working in the national teams using the Big Five Personality Scale for Turkish Culture and the Motivation in Sports Scales. The statistical method of Multiple Regression Analysis was used to test whether there is any statistical significance in the scale of the scale of the Big Five Personality Scale for Turkish Culture and the Motivation in Sports Scales according to gender, age, educational status, age of doing sports, age of being a national athlete and skill level. 
Mumcu, H. E., Alay, S. Ö. / Outdoor and indoor sports that require skill executive branches of the personality types of athletes

\section{FINDINGS}

Table 1. Demographic Characteristics of the Study Group

\begin{tabular}{|c|c|c|c|}
\hline Variables & $\mathbf{X}$ & $\mathbf{N}$ & $\%$ \\
\hline \multirow{2}{*}{ Gender } & Man & 141 & 58.4 \\
\hline & Woman & 98 & 41.6 \\
\hline \multirow{3}{*}{ Age } & $10-17$ & 55 & 23.0 \\
\hline & $18-24$ & 153 & 64.2 \\
\hline & $25-60$ & 31 & 12.8 \\
\hline \multirow{3}{*}{ Education Status } & Primary education & 33 & 13.6 \\
\hline & Secondary - High School & 73 & 31.7 \\
\hline & University & 133 & 54.7 \\
\hline \multirow{3}{*}{ Sports Age } & $1-5$ & 80 & 31.3 \\
\hline & $6-10$ & 69 & 30.0 \\
\hline & $11-15$ & 90 & 38.7 \\
\hline \multirow{2}{*}{ Applied Sports Type } & Outdoor & 140 & 58.4 \\
\hline & Indoor & 99 & 41.6 \\
\hline \multirow{4}{*}{$\begin{array}{l}\text { Age of being a national } \\
\text { athlete }\end{array}$} & $1-5$ & 140 & 58.0 \\
\hline & $6-10$ & 86 & 36.6 \\
\hline & $11-15$ & 13 & 4.9 \\
\hline & Total & 239 & 100.0 \\
\hline
\end{tabular}

The results of regression analysis, dual and partial correlation results for the predictions of athlete's motivation variables according to personality type variables for male and female athletes are given in Table 2 . 
Mumcu, H. E., Alay, S. Ö. / Outdoor and indoor sports that require skill executive branches of the personality types of athletes

Table 2. Regression analysis, dual and partial correlation results for the predictions of athlete's motivation variables according to personality type variables for male and female athletes

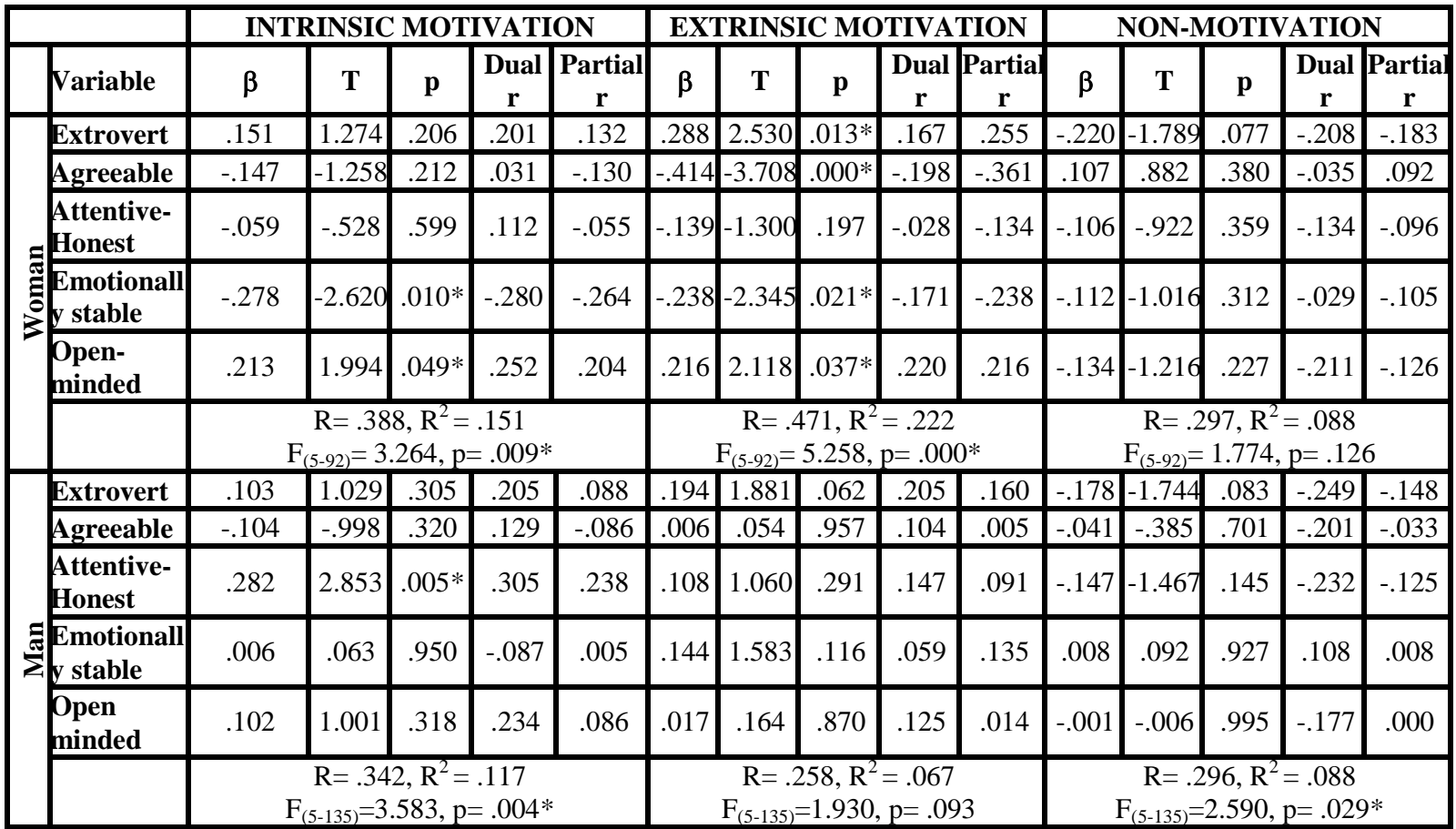

According to Table 2; when the dual and partial correlations between the predictive variables and the intrinsic motivations are examined, it is seen that women have a positive and low level of relationship between extroversion, reconciliation, attentive-honesty and open-mindedness and intrinsic motivation, there is a negative and low level of relationship between emotional balance and intrinsic motivation. The variables of extroversion, reconciliation, attentive-honesty, emotional balance and open-mindedness together have a low and significant relationship with the intrinsic motivation scores of women, $\mathrm{R}=$ $0.39, \mathrm{R} 2=0.15, \mathrm{p}<, 009$.
The five variables mentioned before together account for about $15 \%$ of the total variance in intrinsic motivation. According to the standardized regression coefficient $(\beta)$, the order of importance on the intrinsic motivation of the predictive variables should be emotional balance, open-mindedness, extroversion, reconciliation, and attentive-honesty. When the results of the t-test on the significance of the regression coefficients are examined, it is seen that only the emotional balance and openmindedness variables are significant predictors. Extroversion, reconciliation, and attentive-honesty do not have a significant influence. 
Mumcu, H. E., Alay, S. Ö. / Outdoor and indoor sports that require skill executive branches of the personality types of athletes

Table 3. Regression Analysis Findings, Dual and Partial Correlation Findings on the Predictions of Athletes' Motivational Variables According to Personality Type Variables for Outdoor and Indoor Skills

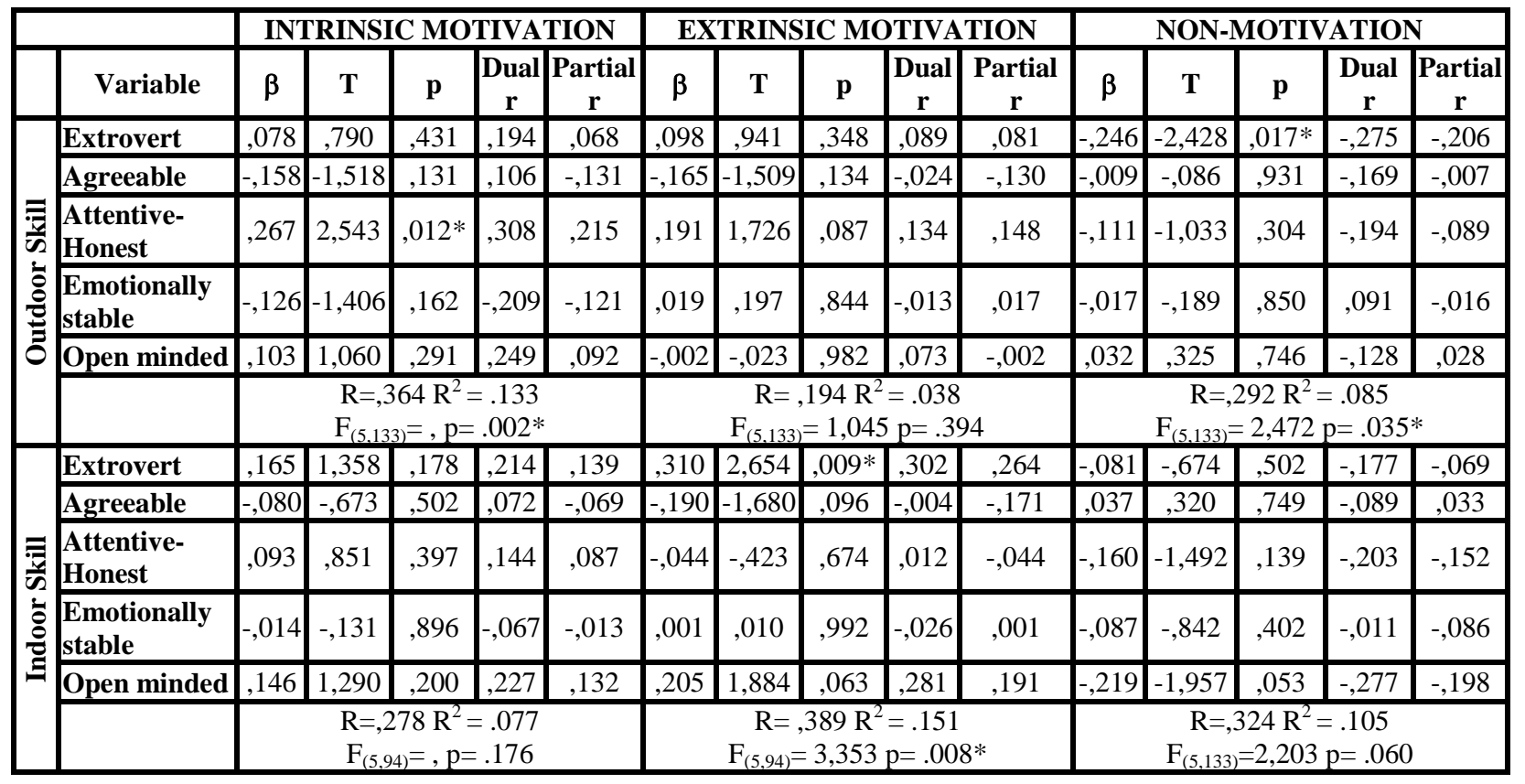

According to Table 3, when the dual and partial correlations between the predictive variables and the intrinsic motivations are examined, it is seen that there is a positive and low level of relationship between extroversion, attentive-honest, open-mindedness, reconciliation and intrinsic motivation of the athletes who perform outdoor skills, and there is a negative and low level of relationship between emotional balance and intrinsic motivation. The variables of extroversion, reconciliation, attentive-honesty, emotional balance and open-mindedness have a low positive and significant relationship with intrinsic motivation scores of athletes who perform outdoor skills, $\mathrm{R}=0.36, \mathrm{R} 2=0.13$, $\mathrm{p}$ $<0.002$. The five variables mentioned before together account for about $13 \%$ of the total variance in intrinsic motivation. According to the standardized regression coefficient $(\beta)$, the order of importance on the intrinsic motivation of the predictive variables is attentive-honesty, reconciliation, open-mindedness, extroversion and emotional balance. When the results of the t-test on the significance of the regression coefficients are examined, it is seen that being attentive-honest is seen as a significant predictor. 
Mumcu, H. E., Alay, S. Ö. / Outdoor and indoor sports that require skill executive branches of the personality types of athletes

Table 4. Regression Analysis Findings, Dual and Partial Correlation Findings on the Predictions of Athletes' Motivational Variables According to Personality Type Variables for Being a National Athlete Age

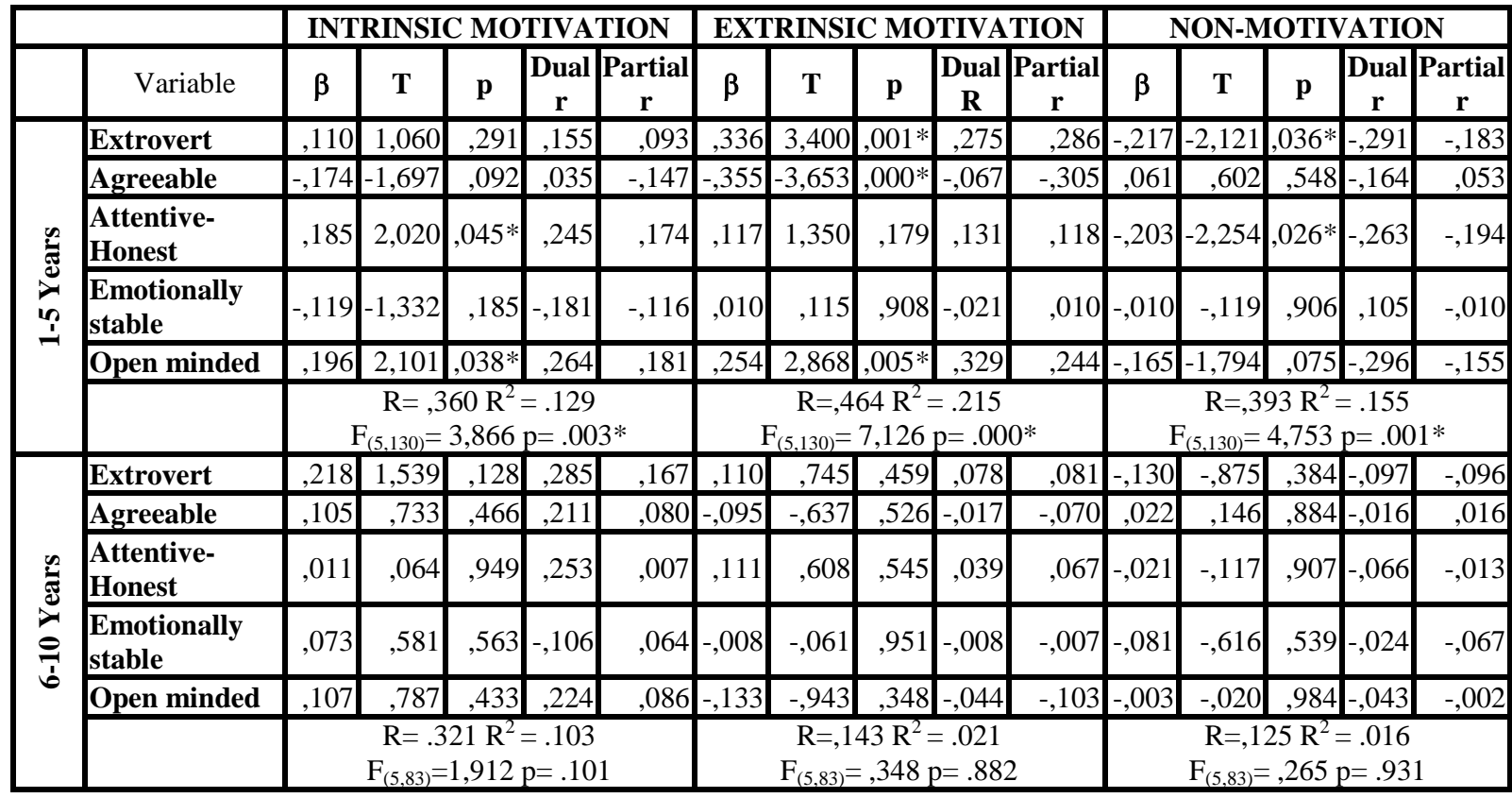

According to Table 4; when the dual and partial correlations between the predictive variables and the intrinsic motivations are examined, it is seen that athletes between the 1-5 years have a positive and low level of relationship between extroversion, reconciliation, attentive-honesty, openmindedness and intrinsic motivation, there is a negative and low level of relationship between emotional balance and intrinsic motivation. The variables of extroversion, reconciliation, attentive-honesty, emotional balance and open-mindedness, together, have a low positive and significant relationship with intrinsic motivation scores of athletes between the 1-5 years, $R=0.36$, $\mathrm{R} 2=0.13, \mathrm{p}<0.003$. The five variables mentioned before together account for about $13 \%$ of the total variance in intrinsic motivation. According to the standardized regression coefficient $(\beta)$, the order of importance on the intrinsic motivation of the predictive variables is open-mindedness, attentive-honesty, reconciliation, emotional balance and extroversion. When the results of the t-test on the significance of the regression coefficients are examined, it is seen that being attentive-honest and open-mindedness are seen as significant predictors.

\section{DISCUSSION AND RESULT}

According to the results of the research; when total personality scores and motivation scores of participants were examined, a negative relationship has been found between intrinsic motivation and a person's emotional balance dimension. This shows that the athletes who have intrinsic motivation do not take part in the dimension of emotional balance from personality types. In sports, the most important instinct/motivation occurs intrinsically. The reason for this is that human beings start to behave with their own free will and end their behaviour when they want, because of the autonomy, competence and connection needs in the Free Will Theory.

It also defines personality as intrinsically motivated human activity and deliberate movements representing its own free will (Deci and Rayn, 1990b). Thus, the more autonomously the athletes participate in the sports, the longer they continue to do sports (Deci and Rayn, 2008). This means, also in the 
sports environment, the presence in that environment of the person with his / her own decision and the display of that behaviour will contribute positively to his / her personality. Participation in the sports environment with external pressures, incentives or awards also diminish motivation over time and cause difficulties in doing the behaviour. As a result, he/she won't be motivated and he/she starts to move away from the sports environment. Initially, participation of all people in the sports environment is either intrinsic or extrinsic (Deci and Rayn, 1985; Deci and Rayn, 1990a; Vallerand et al., 1999; Honca and Cetinkaya, 2017). But it's indicated that intrinsic preferences are more important than extrinsic preferences. Deci and Rayn (1990b) suggest that personal incentives are the reasons for participating in a sporting activity, but they also include recognition, mastery, competitions and related incentives. Personal incentives emerge as a result of the delightful and personal rewards that one receives. Athletes can be motivated to work intrinsically as a result of entertainment, personal development, accomplishing a task. According to the gender variable, from women's intrinsic motivation and personality types, positive and significant relationship with emotional balance, negative and meaningful relationship with openmindedness were found. According to the gender variable, from women's extrinsic motivation and personality types, positive and significant relationship with extroversion and open-mindedness, negative and meaningful relationship with reconciliation and emotional balance were found. According to the gender variable, a negative and nonsignificant relationship was found between women's nonmotivation and all dimensions of personality. A significant relationship was found between women's intrinsic motivation and extrinsic motivation and personality types.

According to the gender variable, a positive and significant relationship was found between the intrinsic motivation of the men and the attentive-honest dimension of the personality. A positive and nonsignificant relationship was found between extrinsic motivation and all dimensions of personality. According to the gender variable, a positive and nonsignificant relationship was found between men's nonmotivation and emotional balance, a negative and nonsignificant relationship was found between all dimensions of personality. A significant relationship was found between men's intrinsic motivation and non-motivation and personality types. This shows us that women experience intrinsic and extrinsic motivations in the sports environment and they are affected positively and negatively by personality traits. These studies have indicated that when gender differences are considered, women show more intrinsic motivation than men (Sarrazın et al., 2002). In another study, it has indicated that men had more tendency to win more than women and that men received the second rank of fair play. In fact, since the participants in youth sports intend to obey the rules and play as good as possible, this information constitutes a strong evidence that they are intrinsically motivated. This tendency stands out more among women. Because it's indicated that fewer women prefer to win, and the majority of them prefer a fair play (Vantensteenkiste and Deci, 2003). But, it's normal that it can differ in some societies and age groups. In research conducted by Brasile (1991), It's indicated that, rather than men, women didn't participate to win sports activities or to compare themselves with others, but they participated for intrinsic and task-oriented reasons. According to the skill state variable, a positive and significant relationship was found between outdoor skills and intrinsic motivation and attentive-honest dimension of personality. A non-significant relationship was found between outdoor skills, extrinsic motivation and all dimensions of personality. A negative and significant relationship was found between outdoor skills, non-motivation and extroversion dimension of personality.

A significant relationship was found between outdoor skills and intrinsic motivation, nonmotivation and personality traits.

According to the skill state variable, a nonsignificant relationship was found between indoor skills and intrinsic motivation and all dimension of personality traits. A significant relationship was found between the indoor skills and extrinsic motivation and the 
extrovert dimensions of it. A non-significant relationship was found between the indoor skills and non-motivation and all dimensions of personality types. A significant relationship was found between the indoor skills and extrinsic motivation and all the personality types. There is no obvious difference when examining the relationship between the type of skill variable and the personality traits of the athletes and their motivation. In the study that we examined the effects of personality types on motivation in the sports environment, positive and negative effects were found on the motivation of some personality types of the athletes. But, these results are valid for certain sports branches and similar studies for all sports branches should be done and psychological tests should be applied widely in the selection of athletes.

According to the variable of age of being a national athlete, a positive and significant relationship was found between the group for 1-5 years and intrinsic motivation with an attentive-honesty and open-mindedness dimension. According to the variable of age of being a national athlete, a positive and significant relationship was found between the group for 1-5 years and extrinsic motivation with an extroversion and open-mindedness dimension. A negative and non-significant relationship was found on reconciliation dimension. A negative and significant relationship was found between the nonmotivation, extroversion and attentive-honesty dimension of the groups of 1-5 years. A negative and significant relationship was found between intrinsic motivation, non-motivation and personality type dimension of the groups of $1-5$ years

According to the variable of age of being a national athlete, a non-significant relationship was found between the intrinsic motivation and all dimension of personality types of the groups of 6-10 years. A non-significant relationship was found between the extrinsic motivation and all dimension of personality types of the groups of 6-10 years. A nonsignificant relationship was found between the non-motivation and all dimension of personality types of the groups of 6-10 years. A non-significant relationship was found between the motivation and the personality types of the groups of 6-10 years. The findings of the study are similar to the previous study results. There is generally no difference between ages and sports.

In a study conducted on 127 athletes whose branch is mountain cross in Germany, intrinsic motivation in both genders is seen as the main source of success. However, there has been a decrease in the level of intrinsic motivation as age increases in the women (Burtscher et al., 2011). When gender differences are considered according to sports age variable, it is seen that women, in general, show more intrinsic motivation than men (Dyrstad et. al., 2002). It is seen that young athletes are more likely to meet other people, to make new friends and to be involved in a group. These results are also similar to the studies carried out before (Lindner and Kerr, 2001; Sarrazın et al, 2002).

All in all; the athlete's personality types show a significant influence and relationship on their motivation. But this influence and relationship is valid for certain sport branches, and the continuation of such researches will give more clear results. Much research has been done on the motivation of the athletes and the identification of the personality types, and the motivation of the athletes has been revealed in general. However, studies on personality types haven't revealed a personality type belonging to the athletes. In this study, it gives a chance to identify the relationship between the personality traits of athletes and the motivation and reveals a chance of making a certain classification. Selection of athletes by psychological tests, not just by talent, and determination of what direction the results are can create a field for future generations that will have more concrete results on sports. The identification of personality types also means to define individuals psychologically. This can create an important database not only in the sports environment, but also in the whole society. 


\section{REFERENCES}

Bakker, F. C., Whiting, H. T. A. \& Van Der Brug, H. (1990). Sport Psyclogy: Concept and Applicantions. New York John Wiley and Sons.

Brasile, F. M., Kleiber, D. A., Harnisch, D. (1991). Analysis of Participation İncentives Among Athletes with and Without Disabilities: Therapeutic Recreation Journal, 25 (1), 18-33.

Burtscher J, Furtne, M., Sachse, P. \& Burtscher, M. (2011). Validation of a German Version of the Sport Motivation Scale (SMS28) and Motivation Analysis İn Competitive Mountain Runners. https://doi.org/10.2466\%2F05.06.25.P MS.112.3.807-820

Deci, E. L., \& Rayn, R. M. (1985). Intrinsic Motivation and Self Determination in Human Behavior. New York Plenum.

Deci, E. L., \& Rayn, R. M. (1990a). A Motivational Approach to Self İntegration in Personality: Nebraska Symposium on Motivation. 38:238-88 https://www.researchgate.net/publicati on/21026291_A_Motivational_Approa ch_to_Self_Integration_in_Personality

Deci, E. L., \& Rayn, R. M. (1990b). The Support of Autonmy and The Control of Behavior: Journal of Personality and Social Pschology 53:1024-1037

Deci, E. L., \& Rayn, R. M. (2008). Facilitating Optimal Motivation and Psychological Well Being Across Life's Domains: Canadian Psychology 49(1),14 DOI: 10.1037/0708-5591.49.1.14

Deci, E. L., \& Ryan, R. M. (2012). Motivation, Personality, and Development Within Embedded Social Contexts: An Overview of Self-Determination Theory: The Oxford Handbook of Human Motivation, 85-107.

Dyrstad, S. M., Miler, B. W. \& Hallen, J. (2002). Physical Fitness Traning Volume, and Self Determined Motivation in Soldiers During a
Peacekeeping Mission. Millitary Medicine 2:121-127.

Gençöz, T., \& Öncül, Ö. (2012). Examination of personality characteristics in a Turkish sample: Development of the basic Personality Traits Inventory. Journal of General Psychology, 139, 194-216. doi:10.1080/00221309.2012.686932

Gill, D. L., Gros, J. B. \& Huddlestone, S. (1983). Participant Motivation İn Youth Sport. International Journal of Sport Psycology 14:1-14

Gould, D. (1982). Sport Psychology in 1980s Status, Direction and Challenge in Youth Sport Research. Journal Sport Psychology. 4 (3), 203-218.

Hagger, M., \& Chatzisarantis, N. (2007). Intrinsic Motivation and SelfDetermination in Exercise and Sport: Leeds, England Human Kinetics Europe Ltd.

Honça, A, Çetinkaya, T. (2017). Perception of Participation Constraints to Recreational Activities: A case of University Students. Uluslararasl Rekreasyon ve Spor Bilimleri Dergisi, 1 (1), 30-37.

Kazak, Z. (2004). Sporda Güdülenme Ölçeği'nin (SGÖ) Türk Sporcuları İçin Geçerlilik ve Güvenirlilik Çalışması: Hacettepe Spor Bilimleri Dergisi 15(4), 56-67

Lindner, K.J., \& Kerr, J.H. (2001). Predictability of Sport Participation Motivation from Metamotivational Dominances and Orientations: Personality and Individual Differences, 30 (5): 759-773.

Martin, J. J., \& Mushett, C. A. (1996). Social Support Mechanisms Among Athletes with Disabilities: Adapted Physical Activity Quarterly, 13(1), 74-83.

Ryan, R. M., \& Deci, E. L. (2007). Active Human Nature: Self-Determination Theory and The Promotion and Maintenance of Sport, Exercise, and 
Health: Intrinsic Motivation and SelfDetermination in Exercise and Sport, 1-19.

Sarrazin, P., Vallerand, R., Guillet, E., Pelletier, L., \& Cury, F. (2002). Motivation and Dropout in Female Handballers: A 21-Month Prospective Study. European Journal of Social Psychology, 32(3), 395-418.

Standage, M., \& Ryan, R. M. (2012). SelfDetermination Theory and Exercise Motivation Facilitating SelfRegulatory Processes to Support and Maintain Health and Well-Being: Advances in Motivation in Sport and Exercise Pp. 233-270

Vallerand, R. J. \& Losier, G. F. (1999). An Integrative Analysis of Intrinsic and Extrinsic Motivation in Sport. Journal of Applied Sport Psychology, 11(1), 142-169.

Vallerand. R. J., Deci. E. L. \& Ryan. R. M. (1987). Intrinsic Motivation in Sport: New York Macmillan. Exercise and Sport Sciences Reviews Vol. 15. 389425).

Vansteenkiste, M., \& Deci, E. L. (2003). Competitively Contingent Rewards and Intrinsic Motivation: Can Losers Remain Motivated? Motivation and Emotion, 27(4), 273-299. 